\title{
Effect of Sky Clearness Index on Transmission of Evacuated (Vacuum) Glazing
}

\author{
Aritra Ghosh \\ University of Exeter \\ Brian Norton \\ Technological University Dublin, brian.norton@tudublin.ie \\ Aidan Duffy \\ Technological University Dublin, aidan.duffy@tudublin.ie
}

Follow this and additional works at: https://arrow.tudublin.ie/dubenart

Part of the Engineering Commons

\section{Recommended Citation}

Ghosh, A., Norton, B. \& Duffy, A. (2017). Effect of sky clearness index on transmission of evacuated (vacuum) glazing. Renewable Energy, 105, pp.160-66. doi:10.1016/j.renene.2016.12.056

This Article is brought to you for free and open access by the Dublin Energy Lab at ARROW@TU Dublin. It has been accepted for inclusion in Articles by an authorized administrator of ARROW@TU Dublin. For more information, please contact arrow.admin@tudublin.ie, aisling.coyne@tudublin.ie,gerard.connolly@tudublin.ie.

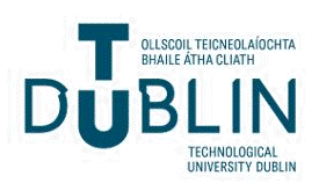




\section{Effect of sky clearness index on transmission of evacuated (vacuum) glazing}

\section{Aritra Ghosh}

aritra.ghosh@mydit.ie

aritraghosh_9@yahoo.co.in

\section{Brian Norton}

Aidan Duffy

Dublin Energy Lab, Dublin Institute of Technology, Dublin, Ireland

${ }^{*}$ Corresponding author

\section{Abstract}

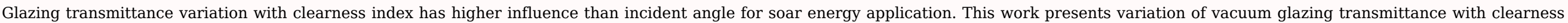

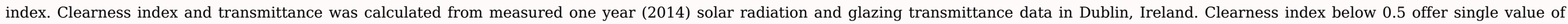

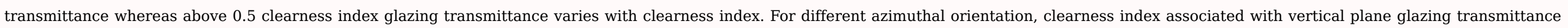

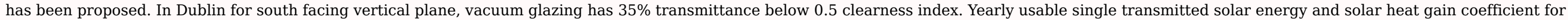
vertical plane south facing vacuum glazing are $87 \mathrm{~W} / \mathrm{m}^{2}$ and 0.22 respectively.

Keywords: Glazing; Clearness index; Vacuum glazing; Transmission; Solar heat gain coefficient; Adaptive

\section{Nomenclature}

I

Incident global solar radiation on the vertical surface of glazing $\left(\mathrm{W} / \mathrm{m}^{2}\right)$

$I_{\text {beam,h }}$

Incident beam solar radiation on the horizontal surface $\left(\mathrm{W} / \mathrm{m}^{2}\right)$

$I_{\text {dif,h }}$

Incident diffuse solar radiation on the horizontal surface $\left(\mathrm{W} / \mathrm{m}^{2}\right)$

$\mathrm{I}_{\text {global,h }}$

Incident global solar radiation on the horizontal surface of glazing $\left(\mathrm{W} / \mathrm{m}^{2}\right)$

$\mathrm{I}_{0}$

Extraterrestrial solar radiation $\left(\mathrm{W} / \mathrm{m}^{2}\right)$

Solar constant $\left(\mathrm{W} / \mathrm{m}^{2}\right)$

$\mathrm{k}_{\mathrm{b}}$ 


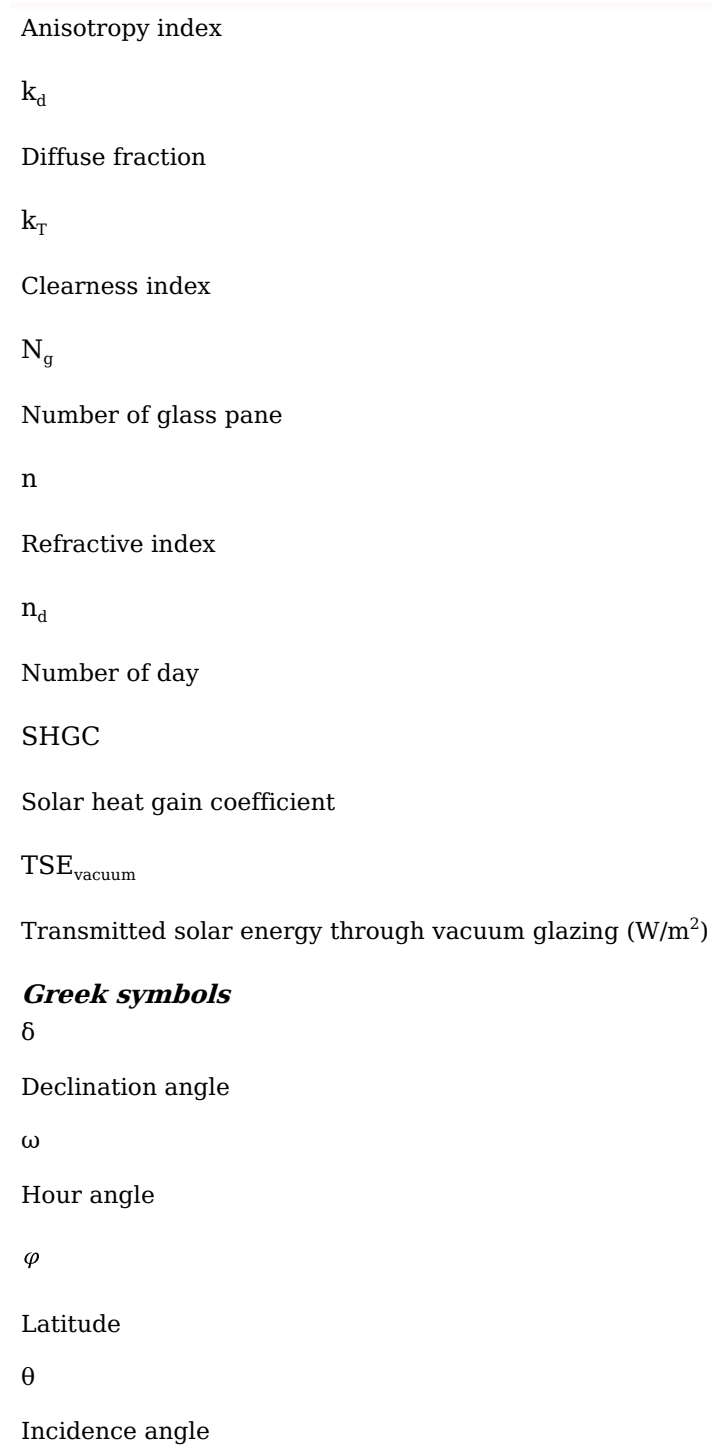

\section{Introduction}

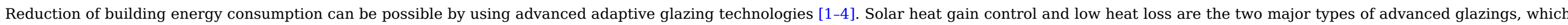

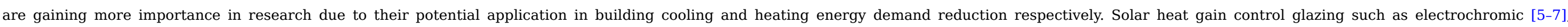

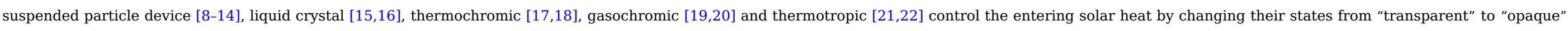

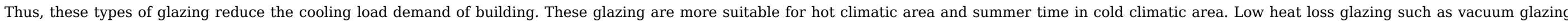

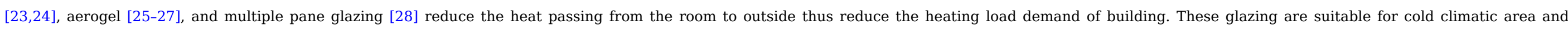
wintertime in composite climate to reduce a building's heating energy demand [24]. 


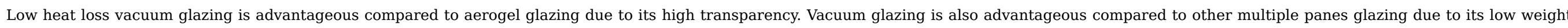

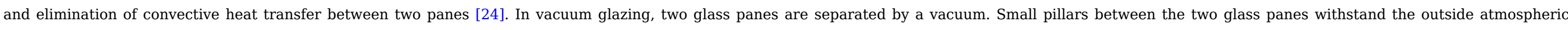

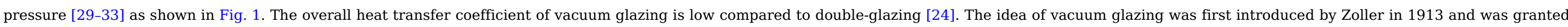

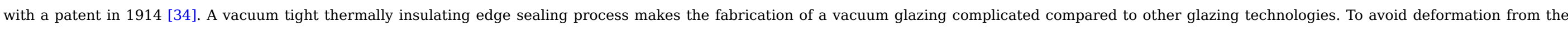

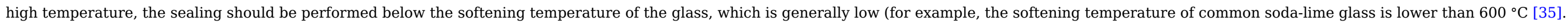
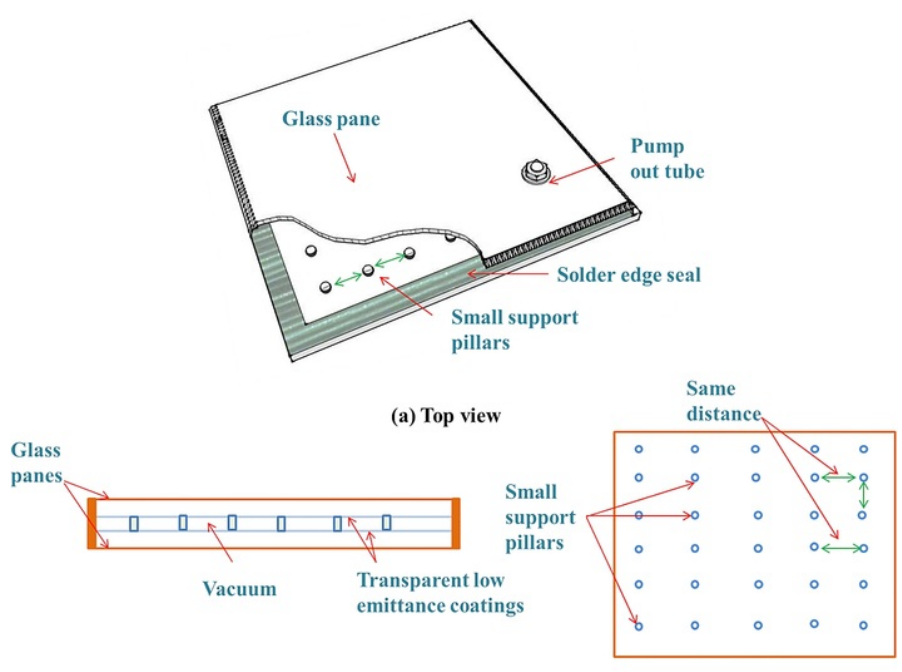

(b) Cross sectional view

(c) Details of support pillars position

Fig. 1 Schematic details of vacuum glazing.

\section{alt-text: Fig. 1}

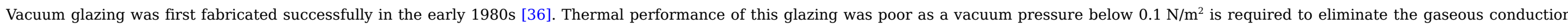
[37]. A laser was used to fuse two sheets of glass together successfully within a vacuum chamber to form a periphery edge seal for the vacuum gap [36-38].

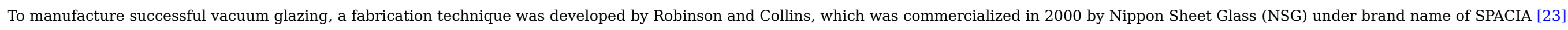

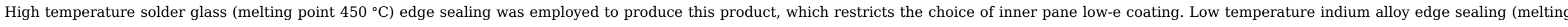

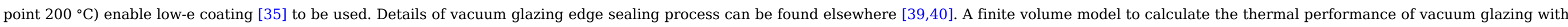

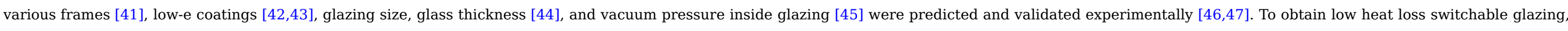
investigation was performed using vacuum electrochromic $[42,48,49]$ and vacuum suspended particle device combinations have been employed [50].

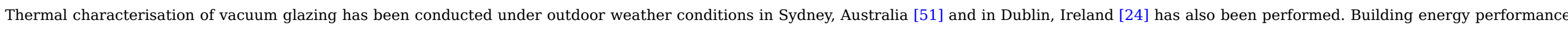

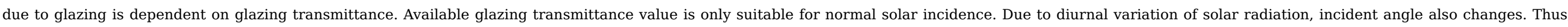

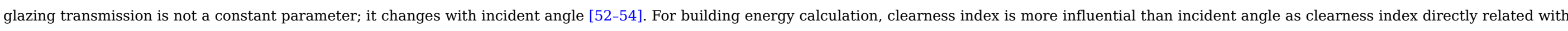

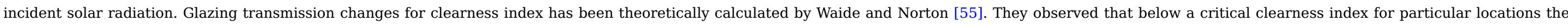
transmission was largely invariant as the diffuse component.

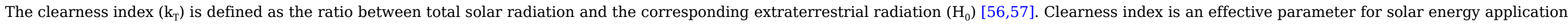

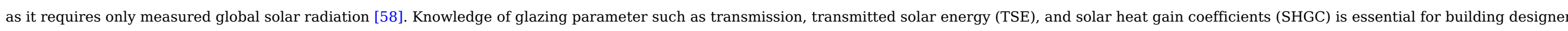

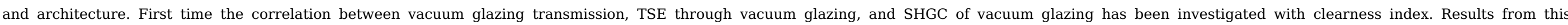




\section{Methodology}

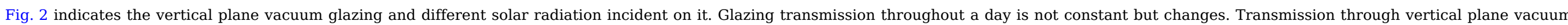
glazing can be written as Equation (1) [24].

$\tau_{\text {vacuum }}=\left[k_{d}\left\{k_{T} R_{b}\left(1-k_{d}\right)+(1-\cos \beta)\left(1-k_{T}\left(1-k_{d}\right)\right)\right\}+R_{b}\left(1-k_{d}\right)+R_{g} \frac{1-\cos \beta}{2}\right] \times \tau_{d i r} R_{b}\left(1-k_{d}\right)\left(1+k_{d} k_{T}\right)+\frac{\tau_{d i f} k_{d}}{2}(1+\cos \beta)\left(1-k_{T}\left(1-k_{d}\right)\right)+\frac{\tau_{g} R_{g}(1-\cos \beta)}{2}$

where Clearness index $k_{T}=\frac{I_{g l o b a l, h}}{I_{0}}$, diffuse factor $k_{d}=\frac{I_{d i f, h}}{I_{g l o b a l, h}}, \quad I_{0}=I_{s c}\left(1+0.033 \cos \frac{360 n_{d}}{365}\right)(\cos \varphi \cos \delta \cos \omega+\sin \varphi \sin \delta)$, and

$\tau=\frac{1}{2}\left[\frac{1-\left\{\frac{\sin (\theta-n)}{\sin (\theta+n)}\right\}^{2}}{1+\left(2 n_{g}-1\right)\left\{\frac{\sin (\theta-n)}{\sin (\theta+n)}\right\}}+\frac{1-\left\{\frac{\tan (\theta-n)}{\tan (\theta+n)}\right\}^{2}}{1+\left(2 n_{g}-1\right)\left[\frac{\tan (\theta-n)}{\tan (\theta+n)}\right]^{2}}\right] \times \exp \left(\frac{-k_{g} N_{g} t_{g}}{\cos \theta}\right)$
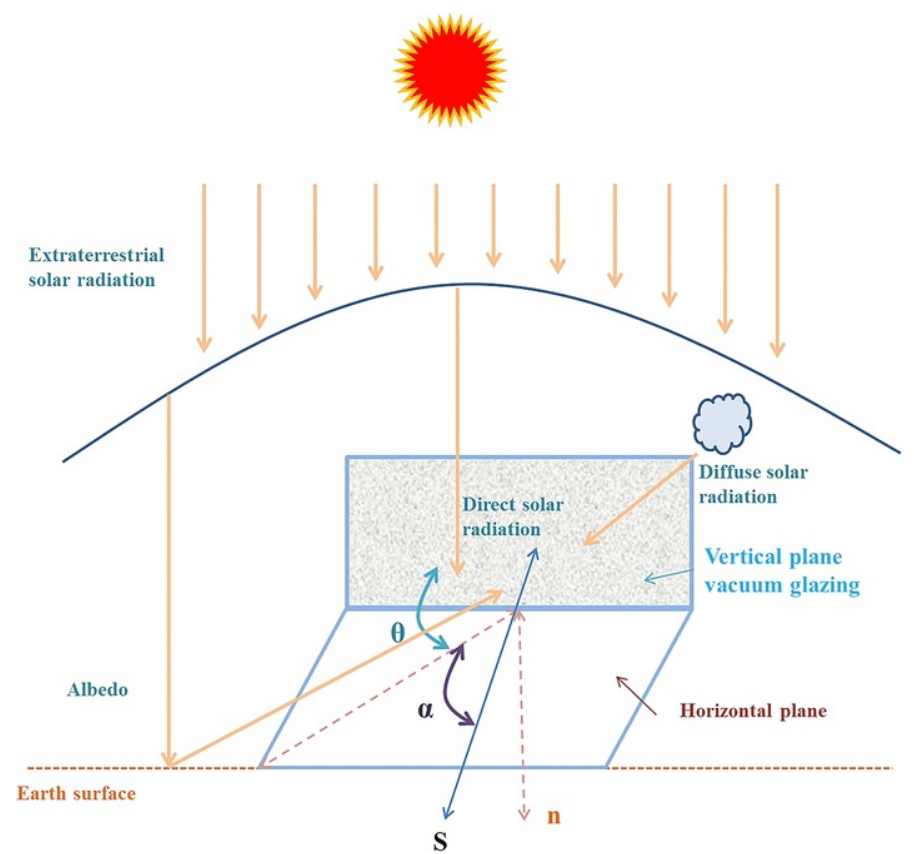

Fig. 2 Schematic diagram of a south facing vertical plane vacuum glazing with incident angle and solar elevation angle.

alt-text: Fig. 2

$\tau=\tau_{d i r}$ when $\theta=\theta_{d i r}$,

$\tau=\tau_{\text {dif }}$ when $\theta=\theta_{\text {dif }}=59.68-0.1388 \beta+0.001497 \beta^{2}$ [59]

and $\tau=\tau_{g}$ when $\theta=\theta_{g}=90-0.5788 \beta+0.002693 \beta^{2}$ [59]

Transmitted solar energy (TSE) for a vertical plane vacuum glazing can be written as Equation (2) [55].

$T S E_{\text {vacuum }}=\left(I_{\text {beam }, h}+I_{d i f, h} k_{b}\right) \tau_{d i r} R_{b}+I_{d i f, h}\left(1+k_{b}\right) \tau_{d i f, h} \frac{(1+\cos \beta)}{2}+I_{g l o b a l, h} \rho_{g} \tau_{g} \frac{(1-\cos \beta)}{2}$ 


\section{Experiments}

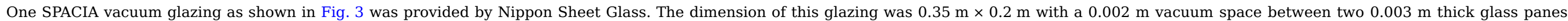

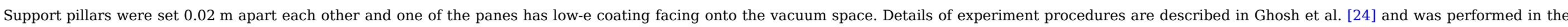

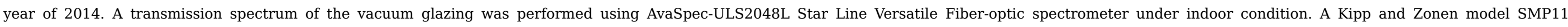
pyranometer was used to measure global solar radiation incident on the vertical surface.

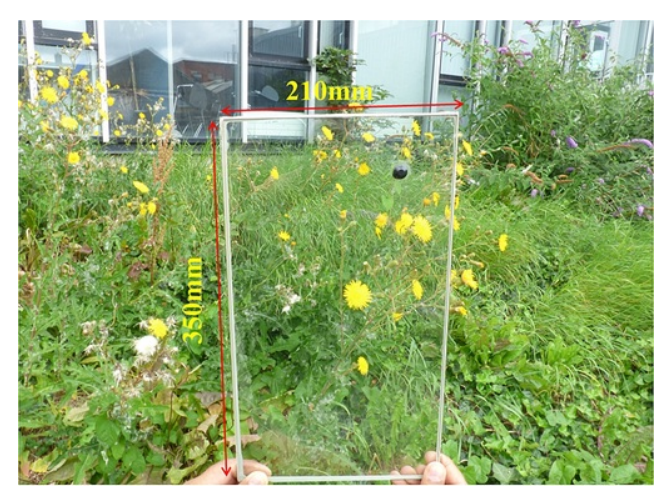

Fig. 3 Photograph of vacuum glazing.

alt-text: Fig. 3

\section{Results}

Fig. 4 represents the vacuum glazing transmission spectra.

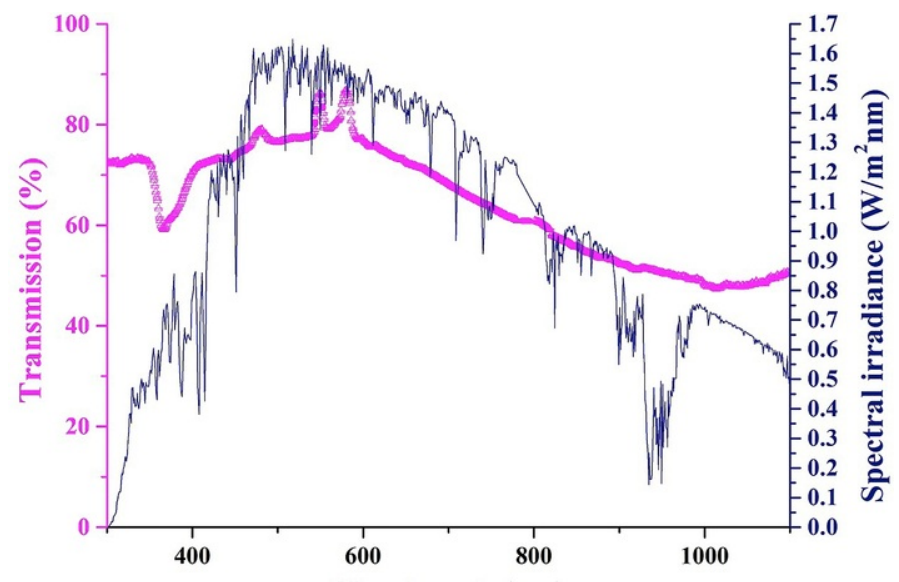

Fig. 4 Transmission spectra of vacuum glazing.

alt-text: Fig. 4 
$R_{\text {vacuum }}=\left(\frac{n_{\text {vacuum }}-n_{\text {air }}}{n_{\text {vacuum }}+n_{\text {air }}}\right)^{2}$

Table 1 Vacuum glazing properties.

\section{alt-text: Table 1}

Vacuum glazing spectral properties

\begin{tabular}{|l|l|}
\hline Solar transmission $(278-1100 \mathrm{~nm})$ & $64 \%$ \\
\hline Solar absorption & $32 \%$ \\
\hline Visible transmission $(380-700 \mathrm{~nm})$ & $72 \%$ \\
\hline Visible absorption & $24 \%$ \\
\hline NIR spectrum absorption $(700-1100 \mathrm{~nm})$ & $8 \%$ \\
\hline
\end{tabular}

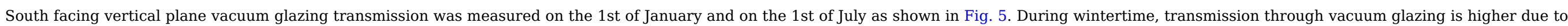
lower elevation angle.

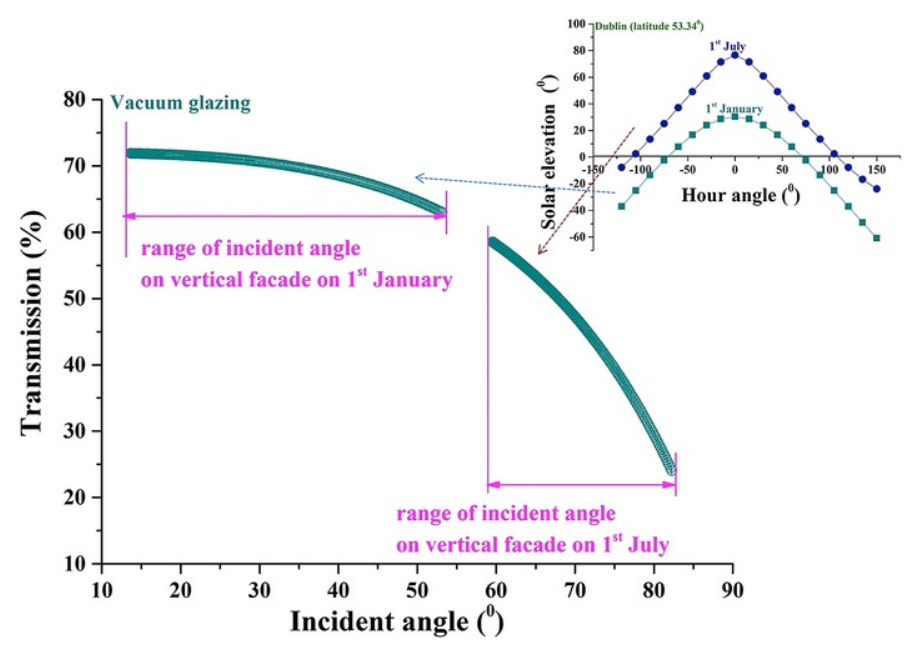

Fig. 5 Variation of vacuum glazing ( $62 \%$ transparent) transmission for different incident angle on 1st of July and on 1st of January.

\section{alt-text: Fig. 5}

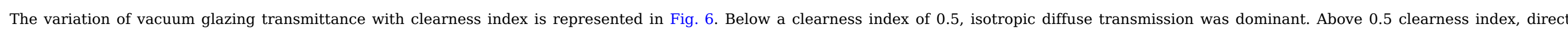

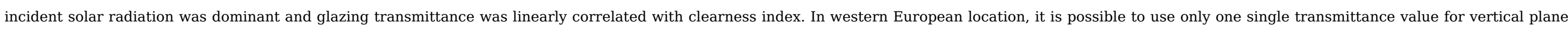

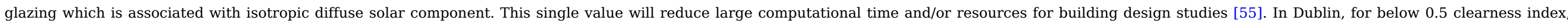

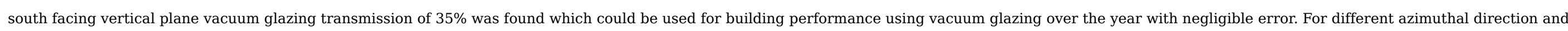
below particular clearness index, one single glazing transmittance can be used with less than $1 \%$ error, which is listed in Table 2 . 


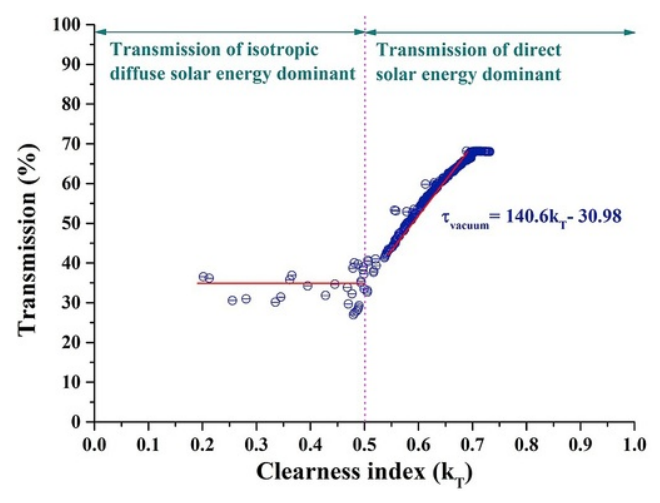

Fig. 6 Variation of vacuum glazing transmittance with clearness index.

alt-text: Fig. 6

Table 2 The clearness index limits for the use of a yearly usable single transmittance, transmitted energy and SHGC value for vertical plane vacuum glazing. alt-text: Table 2

\begin{tabular}{|c|c|c|c|c|c|}
\hline Inclination & Azimuthal orientation & Transmittance & Transmitted solar energy $\left(\mathrm{W} / \mathrm{m}^{2}\right)$ & SHGC & Clearness index \\
\hline \multirow[t]{6}{*}{ Vertical } & North & 35 & 87 & 0.22 & 0.7 \\
\hline & South & 35 & 87 & 0.22 & 0.5 \\
\hline & East & 35 & 87 & 0.22 & 0.6 \\
\hline & West & 35 & 87 & 0.22 & 0.6 \\
\hline & North east & 35 & 87 & 0.22 & 0.6 \\
\hline & North west & 35 & 87 & 0.22 & 0.6 \\
\hline
\end{tabular}

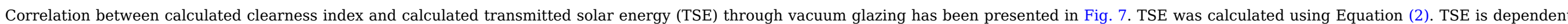

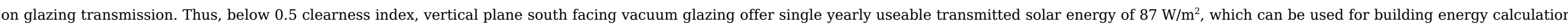

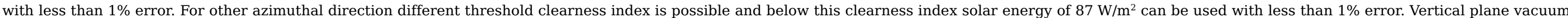
glazing single solar energy for different azimuthal direction and threshold clearness index for that particular azimuthal direction are listed in Table 2.

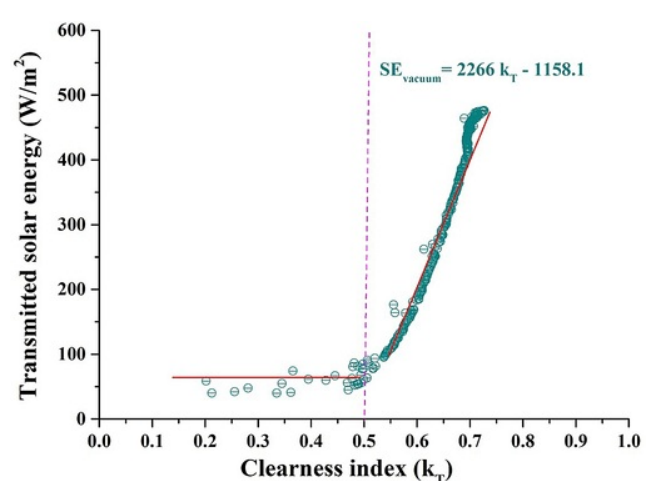




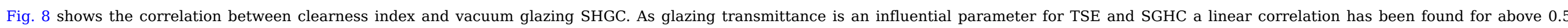

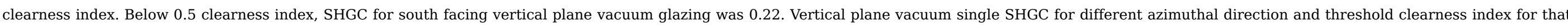
particular azimuthal direction are listed in Table 2.

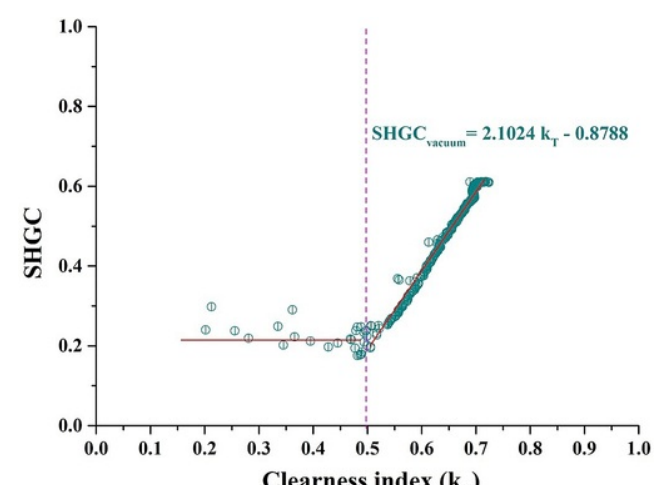

Fig. 8 Variation of solar heat gain coefficient with clearness index

\section{alt-text: Fig. 8}

\section{Conclusions}

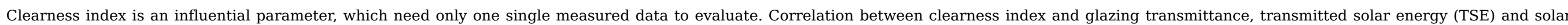

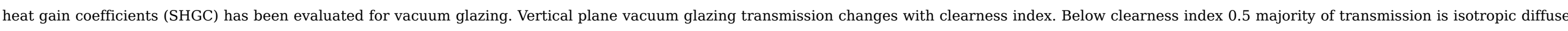

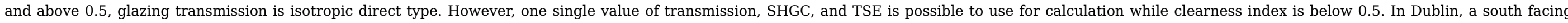

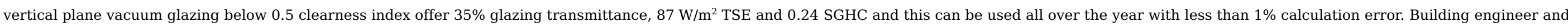
designer based on their own requirement can use these values without complicated calculation.

\section{Acknowledgements}

The work described in this paper was supported by the Graduate Research Education Programme of the Higher Education Authority, Ireland.

\section{References}

[1] C.M. Lampert, Optical switching technology for glazings, Thin Solid Films 236, 1993, 6-13.

[2] C.M. Lampert, Smart switchable glazing for solar energy and daylight control, Sol. Energy Mater. Sol. Cells 52, 1998, $207-221$.

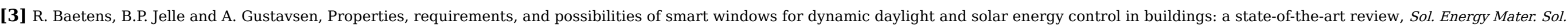
Cells 94, 2010, 87-105

[4] G. Gorgolis and D. Karamanis, Solar energy materials for glazing technologies, Sol. Energy Mater. Sol. Cells 144, 2016, 559-578.

[5] C.M. Lampert, Electrochromic materials and devices for energy efficient windows, Sol. Energy Mater. Sol. Cells 11, $1984,1-27$.

[6] C.M. Lampert, A. Agarwal, C. Baertlien and J. Nagai, Durability evaluation of electrochromic devices - an industry perspective, Sol. Energy Mater. Sol. Cells 56, 1999, 449-463. 


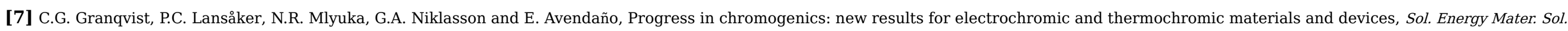
Cells 93, 2009, 2032-2039.

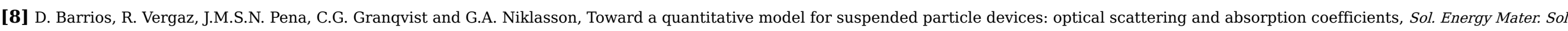
Cells 111, 2013, 115-122.

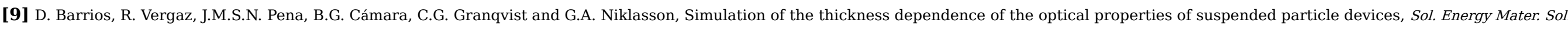
Cells 143, 2015, 613-622.

[10] R. Vergaz, J.M.S.N. Pena, D. Barrios, C. Vázquez and P.C. Lallana, Modelling and electro-optical testing of suspended particle devices, Sol. Energy Mater. Sol. Cells 92, 2008, $1483-1487$.

[11] A. Ghosh, B. Norton and A. Duffy, Measured overall heat transfer coefficient of a suspended particle device switchable glazing, Appl. Energy 159, $2015,362-369$.

[12] A. Ghosh, B. Norton and A. Duffy, Daylighting performance and glare calculation of a suspended particle device switchable glazing, Sol. Energy 132, $2016 \mathrm{a}, 114-128$.

[13] A. Ghosh, B. Norton and A. Duffy, First outdoor characterisation of a PV powered suspended particle device switchable glazing, Sol. Energy Mater. Sol. Cells 157, 2016b, 1-9.

[14] A. Ghosh, B. Norton and A. Duffy, Behaviour of a SPD switchable glazing in an outdoor test cell with heat removal under varying weather conditions, Appl. Energy 180, 2016c, 695-706.

[15] C.M. Lampert, Chromogenic smart materials, Mater. Today 7, 2004, 28-35.

[16] D.J. Gardiner, S.M. Morris and H.J. Coles, High-efficiency multistable switchable glazing using smectic A liquid crystals, Sol. Energy Mater. Sol. Cells 93, 2009, 301-306, 2009.

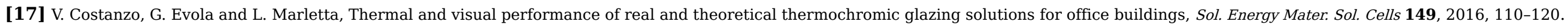

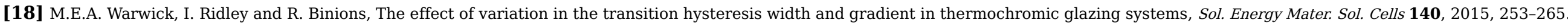

[19] A. Georg, W. Graf, R. Neumann and V. Wittwer, Stability of gasochromic $\mathrm{WO}_{3}$ films, Sol. Energy Mater. Sol. Cells 63, 2000, 165-176.

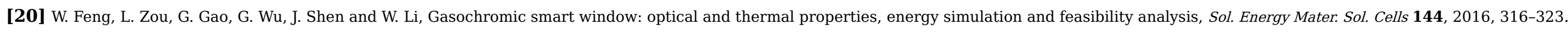

[21] A. Weber and K. Resch, Thermotropic glazings for overheating protection, Energy Proced. 30, 2012, 471-477.

[22] P. Nitz and H. Hartwig, Solar control with thermotropic layers, Sol. Energy 79, 2005, 573-582.

[23] Y. Fang, T.J. Hyde, F. Arya, N. Hewitt, P.C. Eames, B. Norton and S. Miller, Indium alloy-sealed vacuum glazing development and context, Renew. Sustain. Energy Rev. 37, 2014, 480-501.

[24] A. Ghosh, B. Norton and A. Duffy, Measured thermal \& daylight performance of an evacuated glazing using an outdoor test cell, Appl. Energy 177, $2016 \mathrm{~d}, 196-203$.

[25] J.M. Schultz, K.I. Jensen and F.H. Kristiansen, Super insulating aerogel glazing, Sol. Energy Mater. Sol. Cells 89, 2005, 275-285.

[26] C. Buratti and E. Moretti, Experimental performance evaluation of aerogel glazing systems, Appl. Energy 97, 2012, $430-437$.

[27] C. Buratti and E. Moretti, Glazing systems with silica aerogel for energy savings in buildings, Appl. Energy 98, 2012, 396-402.

[28] H. Karabay and M. Arici, Multiple pane window applications in various climatic regions of Turkey, Energy Build. 45, 2012, 67-71.

[29] R.E. Collins and S.J. Robinson, Evacuated glazing, Sol. Energy 47, 1991, 27-38.

[30] R.E. Collins, C.A. Davis, C.J. Dey, S.J. Robinson, J.Z. Tang and G.M. Turner, Measurement of local heat flow in flat evacuated glazing, Int. J. Heat Mass Transf. 36, 1993, 2553-2563.

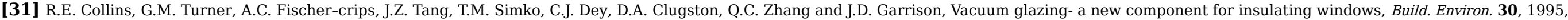
$459-492$. 
[32] R.E. Collins and T.M. Simko, Current status of the science and technology of vacuum glazing, Sol. Energy 62, 1998, $189-213$.

[33] P.C. Eames, Vacuum glazing: current performance and future prospects, Vacuum 82, 2008, 717-722.

[34] A. Zoller, Hohle Glasscheibe, Reichspatentamt, Deutsches Reich, Patentschrift Nr. 387655, (1913).

[35] P.W. Griffiths, Di M. Leo, P. Cartwright, P.C. Eames, P. Yianoulis, G. Leftheriotis and B. Norton, Fabrication of evacuated glazing at low temperature, Sol. Energy 63, 1998, 243-249.

[36] D.K. Benson, C.E. Tracy and G.J. Jorgensen, Laser sealed evacuated window glazings, In: 28th SPIE Int. Symp. on Optics and Electro-optics, San Diego, CA, 1984.

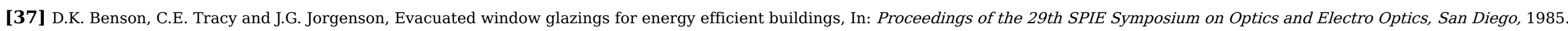

[38] D.K. Benson, C.E. Tracy, Laser sealed vacuum insulation window, US patent 4683154, 1987.

[39] H. Miao, X. Shan, J. Zhang, J. Sun and H. Wang, Effect of sealing temperature on the sealing edge performance of vacuum glazing, Vacuum 116, 2015 , 7-12.

[40] S. Memon, F. Farukh, P.C. Eames and V.V. Silberschmidt, A new low-temperature hermetic composite edge seal for the fabrication of triple vacuum glazing, Vac. 120 Part A 2015 , 73-82.

[41] Y. Fang, P.C. Eames, T.J. Hyde and B. Norton, Complex multimaterial insulating frames for windows with evacuated glazing, Sol. Energy 79, $2005,245-261$.

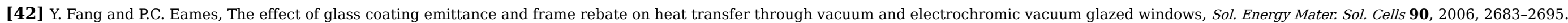

[43] Y. Fang, P.C. Eames, B. Norton, T.J. Hyde, J. Zhao, J. Wang and Y. Huang, Low emittance coatings and the thermal performance of vacuum glazing, Sol. Energy 81, 2007b, 8-12.

[44] Y. Fang, P.C. Eames and B. Norton, Effect of glass thickness on the thermal performance of evacuated glazing, Sol. Energy 81, 2007a, 395-404.

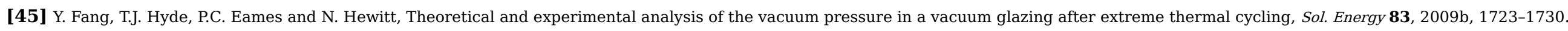

[46] Y. Fang, P.C. Eames, B. Norton and T.J. Hyde, Experimental validation of numerical model for heat transfer in vacuum glazing, Sol. Energy 80, $2006 \mathrm{~b}, 564-577$.

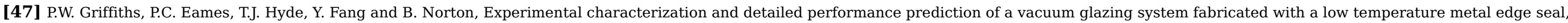
using a validated computer model, J. Sol. Energy Eng. Trans. ASME 128, 2006, 199-203.

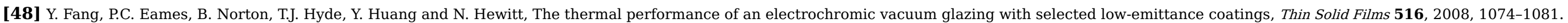

[49] Y. Fang, T.J. Hyde, N. Hewitt, P.C. Eames and B. Norton, Thermal performance analysis of an electrochromic vacuum glazing with low emittance coatings, Sol. Energy 84, 2010 , 516-525.

[50] A. Ghosh, B. Norton and A. Duffy, Measured thermal performance of a combined suspended particle switchable device evacuated glazing, Appl. Energy 169, 2016e, 469-480.

[51] M. Lenzen and R.E. Collins, Long-term field tests of vacuum glazing, Sol. Energy 61, 1997, 11-15.

[52] A. Roos, Optical characterization of coated glazings at oblique angles of incidence: measurements versus model calculations, J. Non-Cryst. Solids 218,1997 a, 247.

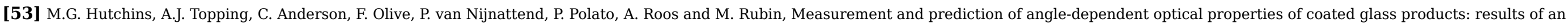
inter-laboratory comparison of spectral transmittance and reflectance, Thin Solid Films 392, 2001, 269-275.

[54] J. Karlsson and A. Roos, Modelling the angular behaviour of the total solar energy transmittance of windows, Sol. Energy 69, 2000, 321-329.

[55] P.A. Waide and B. Norton, Variation of insolation transmission with glazing plane position and sky conditions, ASME J. Sol. Energy Eng. 125, 2003, 182-189.

[56] B.Y.H. Liu and R.C. Jordan, A rational procedure for predicting the long term average performance of flat-plate solar-energy collectors, Sol. Energy 7, $1963,53-74$.

[57] S.O. Udo, Sky conditions at Ilorin as characterized by clearness index and relative sunshine, Sol. Energy 69, 2000, 45-53. 
[58] R. Perez, P. Ineichen, R. Seals and A. Zelenka, Making full use of the clearness index for parameterizing hourly insolation conditions, Sol. Energy 45, 1990, 111-114.

[59] M.J. Brandemuehl and W.A. Beckman, Transmission of diffuse radiation through CPC and flat-plate collector glazings, Sol. Energy 24, 1980, 511-513.

\section{Highlights}

- The variation of vacuum glazing transmittance with clearness index is reported.

- Transmittance dependent TSE and SHGC were evaluated for varying clearness index.

- Below 0.5 clearness index, one single glazing transmittance was found.

\section{Queries and Answers}

Query: Please provide the grant number for "Higher Education Authority", if any

Answer: No number available

Query: Reference [60] have been renumbered as [59].

Answer: thanks for correction

Query: Please confirm that given names and surnames have been identified correctly.

Answer: Yes

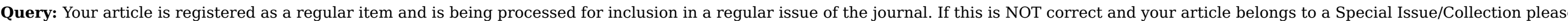
contact v.natarajan.2@elsevier.com immediately prior to returning your corrections.

Answer: Yes 